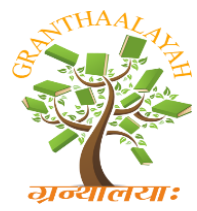

INTERNATIONAL JOURNAL OF RESEARCH GRANTHAALAYAH

A knowledge Repository

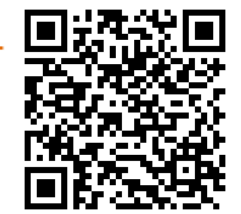

Social

\title{
WOMEN AND THEIR ROLE IN NATURAL RESOURCES: A STUDY IN WESTERN HIMALAYAS
}

\author{
Kiran Singh *1 \\ ${ }^{* 1}$ Research Fellow, Department of Anthropology, University of Delhi, Delhi-110007, INDIA
}

ABSTRACT

Women roles in Himalayas put women in direct contact with natural resources such as forests, water, land and wildlife. They utilize and conserve these resources to supply basic needs for their families. Therefore conservation of natural resources in rural areas cannot be done without the involvement and training of women. They need to be educated on the values, management and sustainability of natural resources as alternative sources of livelihood. But to have success, they must only be appreciated as invisible land managers, but must benefit from relevant incentives in their cultural roles. This paper examines the roles of women in natural resource conservation, since their traditional activities bring them into daily interaction with natural resources, their impacts, attitudes and belief on the management, exploitation and sustainability of natural resource is critical for resource use and sustainability.

Keywords:

Natural Resources, exploitation, Indigenous Knowledge, Domestic economic of poor, Biomass goods.

Cite This Article: Kiran Singh, "WOMEN AND THEIR ROLE IN NATURAL RESOURCES: A STUDY IN WESTERN HIMALAYAS" International Journal of Research Granthaalayah, Vol. 3, No. 10(2015): 128-138. DOI: 10.29121/granthaalayah.v3.i10.2015.2938.

\section{INTRODUCTION}

Himachal Pradesh is located in the western Himalayas. The greater Himalayas, the middle Himalayas, shivalik hills and Dhuladshar hills traverse the state. Himachal means land of snowy mountains. The terrain of Himachal Pradesh is highly varied, with hills, snow- clad lofty mountains, and valleys carved by glaciers and rivers. Within this diversified terrain are three parallel physiographic regions of the Himalayan mountain system. Nearest to the plains of Punjab are the shivalik Hills. Or the outer Himalayas, which have elevations averaging from 3,000 to 5,000 feet (900 to 1,500 meters). To the north of the shivalik are the lesser (or lower).Himalayas which rise to about 15,200 feet. Within this region are the spectular snow-capped Dhauladhar and Pir panjal ranges. Farthest north are the great Himalayas (Himadri) and Zaskar mountains, which tower over the other ranges of this region from heights reaching more than 22,000 feet. Many active mountain glaciers originate in the Great Himalayas. Major rivers in Himachal Pradesh 
include Chenab, (Chandra- Bhaga), Ravi, and Beas in the west and the Sutlej and Yamuna in the east.

It is common knowledge in rural Himalayas that women (and not men) are indeed the (invisible) managers of natural resources. These resources include land, water, forests and wildlife. Most rural women are comparatively poor and uneducated. Most of them do not hold a monthly paying job and therefore are commonly referred to as housewives. But these women are great sustainers of rural micro-economic activities. However nowhere is their impact and activities more significant as their indigenous knowledge of, and management of natural resources such as land, water, forests and wildlife. They are crucial because their traditional gender roles bring them in direct contact with these natural resources, and their survival and that of their families depend directly in exploiting and harnessing supplies from these natural resources. To many poor rural farmers, especially women, nature sustains society because they use the natural resources to feed their families. This sustainability is crucial to them if they have to sustain livelihoods off these resources. Thus when the world environmental protection and conservation policies advocate for protection without any form of use, while ignoring rural women, they become the greatest victims of such a policy.

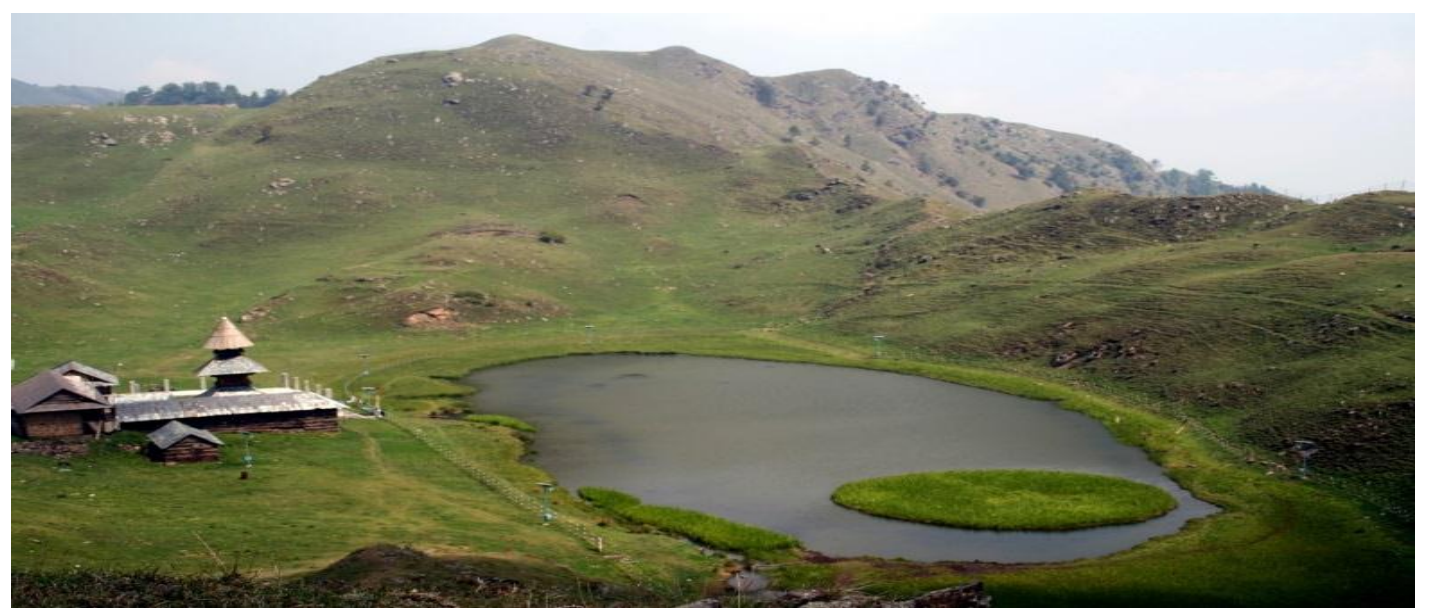

Figure 1: Showing the place where field work has been carried out.

\section{MATERIALS AND METHODS}

A number of research needs related to the role of women in rural natural resource conservation are limitless but a few crucial ones have been identified as follows:

To quantify and evaluate the impacts of women's socio-economic activities on natural resources \{land, water, wetlands, forests and wildlife \} and how this can be ameliorated. Since their traditional activities bring them into daily interaction with natural resources, their impacts, attitudes and belief on the management, exploitation and sustainability of natural resource is critical for resource use and sustainability. 
To quantify the degree of success in the way women run families and rural development and their potential contribution in changing and influencing rural socio-economic progress, especially conservation of land and natural resources; reducing the human rural to urban migration of the youth in search for jobs instead of exploiting rural opportunities as well as in controlling rural explosion \{increase $\}$ of human population.

Public participatory appraisal: The involvement of interested and affected parties in these researches is crucial if the findings will be used to influence their way of life or any policy related to natural resource use. This can be ideal during the initial stages \{Reconnaissance period\}. Key rural development and economic indicators can then be decided upon \{such as small scale trade, subsistence farming, housing and infrastructure, basic life support supplies, etc $\}$. Once this is in place, informal discussions and interviews can be held with women and men to identify resources and their uses, investments in economic and social activities, gender roles in resource management and conservation, gender biases in responsibilities, opportunities and problems. Transecting, mapping, ranking, interviews and triangulation methods can be used.

Household interviews: This can be done both formally and informally with selected household heads \{women or men or both\} to discuss key issues related to gender, rural development and interaction with natural resources. Such interviews can also be held with key informants \{ such as provincial administration, government officials, local government officials, elders etc $\}$

Questionnaires can be designed to isolate and identify key necessary variables that can supply information consistent with the objectives of the research needs. Randomization in distribution to ensure wide spread distribution of questions in primary research area can be done and follow-ups later. In some cases, visits can be done and a member of the research team would actually ask and record answers.

Field observations and measurements: Resource use, land fragmentation, woodlot plantations, water sources and such measurable parameters can be sampled or counted in standard statistical procedures, Case studies in which detailed sampling and measurement of the intensity and extend of resource use and impacts can be done by field observations and measurements.

\section{RESULTS AND DISCUSSIONS}

Women particularly those living in rural areas or mountain areas have special relationship with the environment. They are more close to the nature than men and this very close relationship makes them perfect managers of an eco-system. The life of mountain women is so much intertwine with the environment that whole ecosystem revolves around her and she can't even think of her survival without it. Women have vital role in conservation and management of sustainable eco-system. Since time immemorial, women are traditionally involved in protecting and conserving their natural resources in mountain areas. With their extraordinary skills and traditional knowledge, women have proved how land, water, forest and other natural resources can be used and managed. They have devised their own system and ways to sustain and manage the resources, which are the basis of survival for their families and communities. Through their practical experiences and managerial skills, they have acquired immense knowledge of the various types of plants. They know better than any scientist that what grass, herbs, shrubs, trees are best for them and should be 
planted to maintain a balanced eco-system and wellbeing of their families and communities. They always prefer a mixed forest, which can meet their demands of fuel, fodder, fruits and food as well as maintains the bio-diversity of the mountains. They are perfect in making an optimum use and conservation of natural resources.

Many traditional income-generating activities involving mountain women depend on ample supplies of energy or biomass. In addition to direct sale of firewood or fodder, income is acquired through livestock products (requiring fodder), cheese and butter processing, beer and liquor brewing, processing of agricultural products, raw materials for crafts, charcoal making, and the collection and processing of many non-timber forest products. Non-timber forest products include many essential subsistence items such as fodder, fertilizer, and soil. Both subsistence and smallscale commercial use is made of honey and wax, flowers, seeds, leaves, wild fruits, fibers and flosses, bamboo, rattan, cane and grasses, oil seeds, tans and dyes, gums and resins, pine oleoresins, rubber, drugs, spices, aromatics and insecticides, sandalwood, and seeds for propagation. Sustainable harvesting and processing of these resources generate significant income for women and community cooperatives.

\subsection{THE LINKAGE BETWEEN WOMEN, NATURAL RESOURCE AND THE DOMESTIC ECONOMICS OF POOR RURAL HOUSEHOLDS ARE CLEAR AND CATEGORIZED INTO THREE PATTERNS}

1. First natural resources are central to the livelihood in India. Many studies have documented that poor household are dependent on free biomass and common property resources.

2. Second, women are the primary gatherer and managers of biomass goods in poor rural households. They also play an important role in the processing, storing, utilization and marketing of biomass goods.

3. Women's role and responsibility are pivotal not only to the management of natural resources but also to the management of domestic economy. Studies have shown that women work longer hours and assemble more of their income to household budget. They effectively manage the day to day consumption and cash- flow needs.

The women have deep relationship with all the components of ecosystem. The perfect ecosystem can be maintained only when women will be recognized as the best manager of eco system. The relationship of land, water, forest, animal with each other can be understood only by women in a broader and more holistic way than anyone else. Therefore they should be given opportunity to participate in the village ecosystem planning.

\subsection{WOMEN AND AGRICULTURE}

Agriculture remains the key source of livelihood for India as well as Himachal Pradesh. In Hilly States like Himachal Pradesh, the traditional farming operation is a complex product of crop husbandry, animal husbandry and forest resources, which constitute interlinked diversified production systems. Inaccessibility, environmental heterogeneity and ecological fragility favored the evolution of subsistence production systems sustained with organic matter and nutrients derived from the forest. Such production systems are the reservoirs of a huge variety of crops and 
cultivars many of which are still lesser known to the mainstream societies and are better adapted to eco-environmental and geo-climatic conditions and social set up as compared to the modern agriculture systems. The hilly women are repository of knowledge (local techniques and technologies) that has evolved over a long period of time after excessive informal trial and error and plays vital role in agriculture system.

Women play important role in agriculture as it is largely household enterprise. The studies have highlighted those women in India play a major role in production of food and number of hours worked. The women constitute about half of the total population of the country and of which $75 \%$ are purely the rural women alone. Agriculture is the major field of employment in India involving $78 \%$ of total women population of the country. Nearly $63 \%$ of the men are engaged in Agriculture as compared to $78 \%$ of women. Almost $50 \%$ rural female population is classified as Agricultural laborers and $37 \%$ as cultivators. The corresponding population of male rural workers is reverse with $55 \%$ as cultivators and $24 \%$ as agricultural laborers. This is how one can portray the country's scenario of women engaged in Agriculture/Allied activities.

The Rural women in Himachal play a predominant role in terms of both number of activities and time spent performing them. Usually, these are low skill tasks entailing drudgery. Due to male out migration, women are left to perform all agricultural operations on terraced fields-except ploughing. It is a religious decree that saves her from this operation.

Table 3.1: Showing the gender based percentage share in agricultural and animal husbandry activities.

\begin{tabular}{|l|l|l|}
\hline $\begin{array}{l}\text { GENDER BASED } \\
\text { PERCENTAGE SHARE IN } \\
\text { AGRICULTURAL AND } \\
\text { ANIMAL HUSBANDRY } \\
\text { ACTIVITIES }\end{array}$ & PERCENAGE SHARE \\
\hline ACTIVITY & MEN & \\
\hline AGRICULTURE & 100 & WOMEN \\
\hline Plough in & 15 & 00 \\
\hline $\begin{array}{l}\text { Land preparation and cold } \\
\text { breaking }\end{array}$ & 28 & 72 \\
\hline Sowing and transplanting & 0 & 100 \\
\hline Gap filling & 32 & 68 \\
\hline Interculture & 6 & 94 \\
\hline Weeding & 50 & 50 \\
\hline Irrigation & &
\end{tabular}




\begin{tabular}{|l|l|l|}
\hline Fertilizer application & 55 & 45 \\
\hline Harvesting & 29 & 71 \\
\hline Threshing and winnowing & 42 & 58 \\
\hline \multicolumn{2}{|l|}{} \\
\hline ANIMAL HUSBANDRY & \multicolumn{2}{|l|}{} \\
\hline Tending cattle in shed & 5 & 95 \\
\hline Grazing & 52 & 48 \\
\hline Removing dung from shed & 0 & 100 \\
\hline Fodder collection & 7 & 93 \\
\hline Milking & 4 & 96 \\
\hline
\end{tabular}

Women perform a variety of task such as weeding, hoeing, fertilizers application, plant production, and harvesting, threshing, winnowing and other miscellaneous works. Women also participate in the activities like snowing, transplanting, irrigation, growing vegetables, planting fruit plants, collecting fuel, plucking, picking food grain and their storage. Women supervise the activities as arranging for sale of the products, storing hey, picking of pods and vegetables, unsealing of maize cobs, cutting and weeding, transplanting seedlings and sowing. For the selected agricultural decisions like amounts of grain used, stored and sold, women are usually more consulted? Women's play important role in the farm management and other decision making processes, employment of family and casual labor for operations like sowing, weeding, buying of new cattle and equipment's, selling and buying of new property. Women are the sole decision maker in the families where male members migrate to earn.

\subsection{WOMEN AND HORTICULTURE}

Himachal Pradesh by and large is involved in Agriculture/Allied activities and traditional crops like Maize, Wheat and Barley are grown here but off late, vegetable cultivation has taken significant stride. Fruit cultivation in Himachal Pradesh has already become a history of half a century. Fruit and vegetable cultivation has started gaining importance on commercial lines and after reaching heights in mid and higher regions of the state; it is taking comfortable lead in lower parts of the state also. In cultivation of crops, fruits, vegetables, flowers, honey, mushroom, hops and medicinal plants, hill women has been playing a pioneer role. The success attained in fruits and vegetable production can wholly be attributed to the efforts of hill women who are day and night involved in this task. The credit goes to women for making Himachal Pradesh the 'Apple State of India' since the rural women had been carrying out the horticulture activities dedicatedly. Role of women in hill farming system is very important especially in fruit and vegetable cultivation 
besides in conventional farming. Hill women have been contributing in following way in boosting farming activity especially in Horticulture.

- Preparation of land, including removal of bushes and clearance of land where orchard is to be raised, terracing of land and layout of orchard and fencing of the orchard.

- Preparation, digging, filling of pits after mixing of FYM.

- Plantation of fruit plants in pits and staking of the same.

- Irrigation of the orchard.

- Application of fertilizers and Manures.

- Weeding of orchard and basin making

- Removal of diseased branches and twigs.

- White washing of trunks of the orchard trees.

- Watch and ward of crop against animals and birds

- Picking, grading and packing of fruits.

- Collection and staking of packing material.

- Marking of boxes and even transportation of packed material to road head.

- Spraying and plant protection.

- Home made products like pickle, Muraabas, wine making

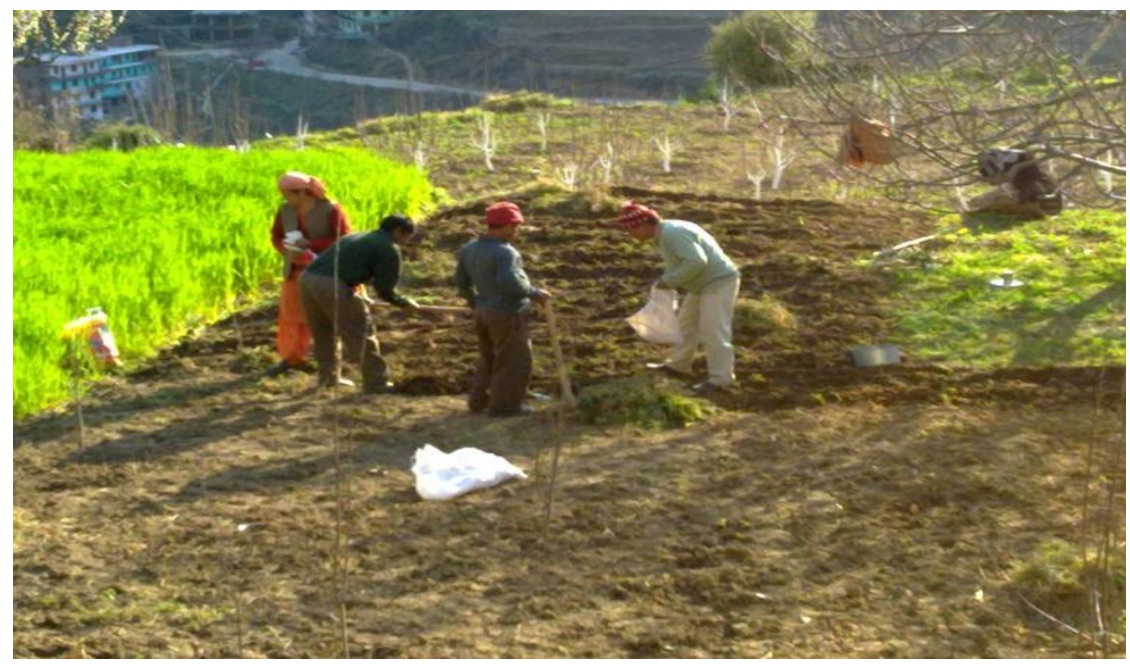

Figure 3.1. Women working in field

\subsection{WOMEN AND FOREST MANAGEMENT}

The day-to-day survival of families in rural Himachal Pradesh depends on the forests. The forest and water are the most important factors in the daily work and life of Hilly rural women and out of these, forests are considered most important. For her, forest is her mother's home as she is entirely dependent on the forest to meet her daily needs such as- water, fodder, fuels, minor forest produce etc. As a result of the gender division of work, it is primarily women who are the major gatherers of a wide range of Non Timber Forest Products (NTFP) for subsistence and as a source of income. Women are also employed along with men in forestry operations of the forest and other 
Departments. An emerging understanding of above said participation of women in forest related activities has triggered interest of society in studying the role of women in forestry and the forest economy.

The women play important role in forestry in essentially three areas:

1. Gathering fuelwood, fodder

2. Cultural belief about Forest

3. Protection and management.

\subsubsection{GATHERING FUEL WOOD, FODDER}

Gathering firewood, or "head loading" as it is often called, for domestic use and as a source of income is the most widespread gender-based activity for poor women. It has been estimated that two to three million people are engaged in head loading, with the majority being tribal and other poor women. In Himachal Pradesh and Uttaranchal, very little fodder is grown on agricultural land and livestock graze mainly in pastures and forests. In these regions, tree fodder is predominant and it is mainly women who manage lopping and fodder collection. As many of these regions have a high degree of male migration, the responsibility of agriculture and animal husbandry lies with women. Gathering of fuel wood, fodder and NTFPs is an important subsistence and economic activity for poor women. The relative status of women within the family is higher in well-forested villages/ villages close to natural forests, because their contribution to subsistence and cash incomes of households is greater. Moreover, as their ownership of private resources is negligible, women, particularly those who are poor, depend heavily on common resources for meeting their survival needs.

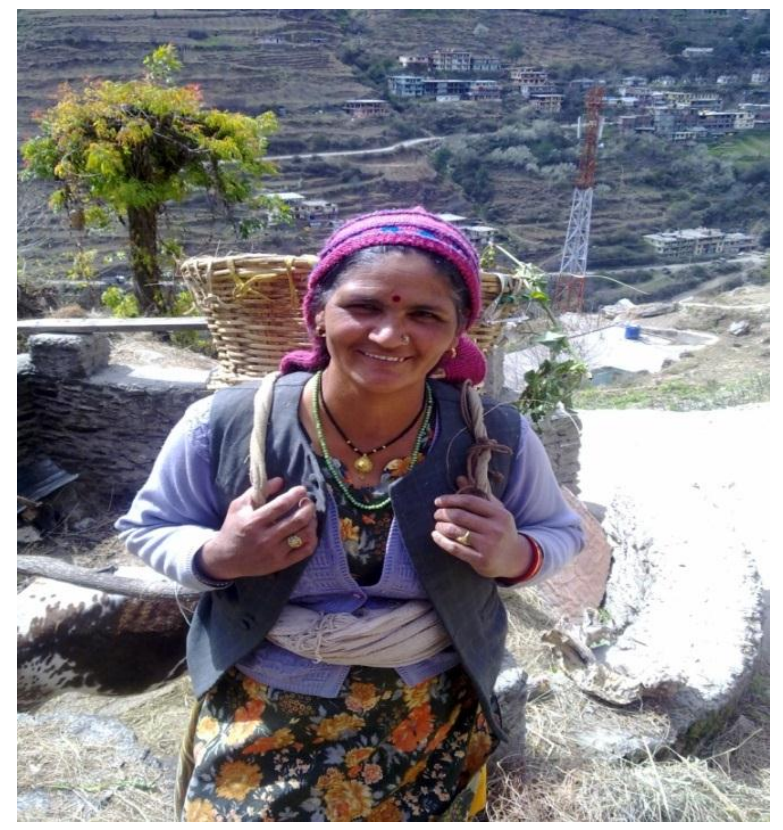

Figure 3.2: Showing women collecting firewood 


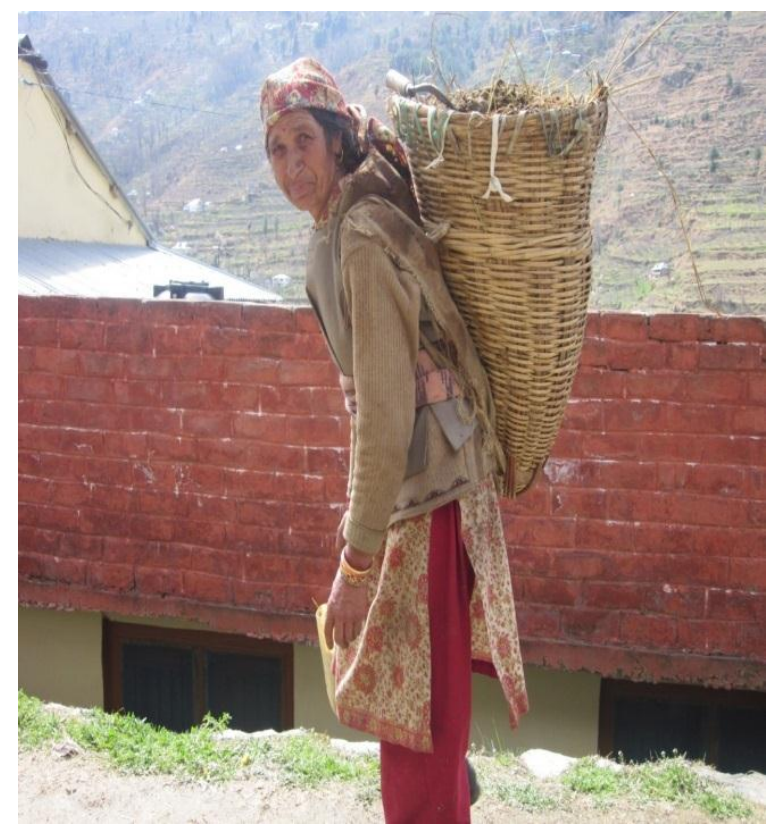

Figure 3.3: Showing women coming from field after collecting firewood.

\subsubsection{CULTURAL BELIEF ABOUT FORESTS}

Forests are integral to the "Cosmo vision" of indigenous communities of the study area. Which manifest in a direct relationship between cultural events and beliefs with tree or forest. For example no person is allowed to go to the forest every time. They only visit for some specific purpose only .In forest person should not talk in the loud voice, or shout or laugh because it's believe that in the tree of forest there is existence of the "Kali" roop (negative face). she immediately enters into the body of the person and also harm to them. While attacking of "kali matri "The person body they loss their mental ability etc. The women are strictly not allow when is going through menstruation days. Basically "kalio ke bhaan' leaves in the mountain from the forest shaman and priest use to collect the branches of tree use in worship.There are 15 types of water used for worship which is collected from the forest.

In the forest there is tree name Bhoj tree from which Bhoj patra (yantra is made up of).bhoj patra is basically the skin of their old tree. Bhoj tree is also used in medicinal values like for backpain, thigh pain .Bhoj part a is used to being in their vessel called (lota) then it's apply to the area of pain.

Most people believe that ancestral spirits also come and rest on these trees. There is fear of redistribution that they will be punished by kali if they harm the tree is common amongst all age group and classes.

The local knowledge of forest/tree resources for cultural /religious purpose is within the complex social network of area. 
Table 3.2: Showing local names of herbs and their uses.

\begin{tabular}{|c|c|}
\hline Local Names & Uses \\
\hline Ghass - (Khusha) & used for worship \\
\hline Viva ghass & $\begin{array}{l}\text { very flexible it can be also spiral in shape and } \\
\text { used to make rope }\end{array}$ \\
\hline Ghass & $\begin{array}{l}\text { used for organic fertilizer by mixing gobbar } \\
\text { and one kechu to prepare khaad for ground }\end{array}$ \\
\hline Bhangjidi & It' used in chutney,roti \\
\hline Soyabean & For halwa,kheer. \\
\hline Kakad tree- & $\begin{array}{l}\text { Used to make medicine for cough .Prepartion- } \\
\text { Its leaves by drying it. Then burn it on gas, } \\
\text { make kadha then mix it with honey. Take it in } \\
\text { every morning and evening. }\end{array}$ \\
\hline Ajwaeen and Kaala namak & $\begin{array}{l}\text { Used for gastric problem with luke warm } \\
\text { water. }\end{array}$ \\
\hline Kinshu tree & Seed used in adultration in tea. \\
\hline Ulci oil & $\begin{array}{l}\text { Used to protect from insect to apple. It's mix } \\
\text { with blight tox. }\end{array}$ \\
\hline Chopalia & Used to spray on apple \\
\hline
\end{tabular}

\section{CONCLUSIONS}

Women in rural areas are more linked with natural resource use and conservation than men. Their traditional gender roles bring them in daily contact with natural resources such as land, water, forest and wildlife. They have to use these resources because they are often poor and their livelihood most depends on these resources. When these resources are exploited and ruined, women suffer most. If they are wisely used sustainably women benefit most. Most of the activities in Himalayas are done by the women either its household or fieldwork. Most women want to learn and to be recognized for what they really are: managers of natural resources. The choice to involve women is a choice for sustainability, it's a choice that will empower rather than increase conflicts over limited highly needed natural resources, and it's a choice that will lead to conservation of natural resources being lost to consumptive and exploitative land use alternatives. The basis is to allow traditional use and benefit, yet elicit responsibility with such rights and privileges so that at the end, benefits are close linked with conservation responsibilities.

\section{ACKNOWLEDGEMENTS}

I would like to heartily thankful to Prof. A. K. Kapoor, Department of Anthropology, University of Delhi. I would also like to show my gratitude to Prof. A. K. Sinha from Anthropology Department, Panjab University, Chandigarh for his valuable suggestions and Guidance from time to time. I would also like to thanks my entire respondent from Village of Himachal Pradesh for their support and co-operation for their precious time, blessings and support during my fieldwork 
especially Dubey Ji for motivation. And last but not the least i would love to express my love to my Father Mr. P.K. Singh and Mother Mrs. Meera Singh.

\section{REFERENCES}

[1] Aggarwal, B. "Rural women, Poverty and Natural Resources: Sustenance, Sustainability and struggle for change." Economic \& political Weekly, 1989: WS46-WS65.

[2] Aggarwal, $R, N$ Sinaia, and $C$ Romano. "Access to natural resources and the fertility decision of women: the case of South africa." .Environment and Development Economics, 2001: 209-236.

[3] Angus, S. "Women in Ntaural Resources: Stimulating Thinking about Motivations and Needs. ." Wildlife society Bulletin, 1995: 23(4):579-582.

[4] Bhatta, $R$, and K A Rao. "Women's livelihood in fisheries in Coastal Karnataka, India." Indian Journal of Gender Studies, 2003: 10(2):261-278.

[5] Dasgupta, P. "An Inquiry into well-Being and destitution." Oxford University Press, 1993.

[6] Hardy, S B. "Mother Nature: A History of Mothers, Infants and Natural selection." Politics and Life Science, 2001: 246-247.

[7] Joshi, P C. "Role of Culture in Social Transformation and National Integration." Economic and Political weekly, 1986: 21(28):1224-1232.

[8] Kevane, M, and B Wydick. "Social norms and time allocation of women's labour in Burkina Faso. ." Review of Development Economics, 2001: 5(1):119-129.

[9] Lama, A, and M Buchy. "Gender, Class, caste and participation: The case of community forestry in Nepal." Indian Journal of Women's Studies, 2002: 9(1):28-41.

[10] Panhwar, F. "women and Organic agriculture in Pakistan." Sindh rural womens Uplift Group, Pakistan, 2001.

[11] Ramamurthy, P. "The cotton commodity chain, women, work and agency in India and Japan: The Case for feminist agro-food systems research." World Development, 2000: 28(3):551-578.

[12] Rath, S. "Grape cultivation for exports: impact on vineyard workers." Economic and Political weekly, 2003: 38(5):480-489.

[13] Sarin, M. "Empowerment and disempowerment of forest women in Uttarkhand, India." Gender,Technology and Development, 2001: 5(3):341-364.

[14] Sen, I. "Class and Gender in work Time." Economic and Political weekly, 1988: 23(33).

[15] Singh, C. "Common Property and Common poverty." discussion paper, Oxford University Press Delhi, 1986.

[16] Taylor, C E, and R Faruque. "Child and maternal service in rural India: The Narangwar Experiment,Part I." John Hopkins University press, baltimore and London, 1983.

[17] Upadhyay, B. "Forthcoming. Gendered livelihoods and multiple water use in North Gujarat." Agriculture and Human Values.Kluwer Publication, Dordrecht, The Netherlands., 2004: 22;3.

[18] Upadhyay, B, and V Bhamoriya. "Women in organic agriculture: Reflections from Madhya Pradesh, India. ."s Appropriate Technology. research Informations Limited, U.K., 2004. 